\title{
TRANSITIONAL JUSTICE AND PEACEBUILDING IN AFRICA: NEXUS OR NEMESIS? ${ }^{1}$
}

\author{
Muhamad Danial Azman
}

\begin{abstract}
In what way have liberal peacebuilding interacted with the mechanisms commonly associated with Transitional Justice (TJ), and how has this enriched the debate of liberal peace and democracy in Africa? In two parts, this article briefly elucidates the intersection between Transitional Justice (TJ) and liberal peacebuilding. The first part begins by revising Oliver Richmond's four generations of practices in peacebuilding. A particular emphasis will be placed here on the fourth, most contemporary framework for liberal peacebuilding, and the major criticisms that it has received in Africa. The second part acknowledges the sustained criticism of liberal peace in Africa, which is key to understanding the growing relevance of the 'justice versus peace' debate in two specific forms of post-conflict reconstruction experiments in Africa. Three are: (i) transformation from peacekeeping to peacebuilding; (ii) a paradigm shift from the normative, liberal peace conviction that justice is a good project, to a legal, consequentialist argument that peace cannot be lastingly sustained without some form of criminal prosecution, resulting the increasing usage of human rights language in drafting peace agreements. The aims is to highlight the deeper affinity and deficiency that can be viewed as two sides of the same coin in the liberal cosmopolitan approach to postCold War International Relations (IR): peacebuilding as a political project concerned with sustainable peace, and TJ as a legal project that concerns itself with evaluating the modes of justice during the transitional phase.
\end{abstract}

Keywords: Transitional justice, peacebuilding, liberal peace, democracy, human rights, violence, conflict, Africa 


\section{INTRODUCTION}

Most post-conflict peacebuilding literature is normative and concerns itself with the 'political question' of rebuilding the state; meanwhile the Transitional Justice (TJ) literatures is mostly concerned with not only the 'legal question' of how to strengthen the rules of law, security and order, but also the political implication of adopting legal and non-legal mechanisms in post-conflict reconstruction policy. ${ }^{2}$ "Traditionally, peacebuilding and transitional justice literatures and practice either have not engaged one another or have been in tension or even opposition."3 The past twenty years have seen the proliferation of TJ mechanisms, such as criminal tribunals and truth commissions, which promise accountability for perpetrators and redress for victims in the wake of authoritarianism and civil war. ${ }^{4} \mathrm{TJ}$ efforts may include, but are not limited to, criminal tribunals, truth commissions, lustration, institutional reforms, public memorials, reparations, and amnesties. ${ }^{5}$

The origins of TJ can be traced back to the post-World War Two tribunals in Nuremberg and Tokyo respectively, where, for the first time, responsibility for large-scale human rights violations and mass atrocities was attributed to political perpetrators (individual accountability) rather than sovereign states (collective accountability). ${ }^{6}$ With the development of the ad-hoc tribunal in the former Yugoslavia (1993) and Rwanda (1994) and the establishment of permanent body of the International Criminal Court (ICC) (2003), the UN promoted a theme of peacebuilding through law. ${ }^{7}$ The 2004 UN report on the Rules of Law and Transitional Justice in Conflict and Post-conflict Societies has arguably 'neologized' the international liberal peacebuilding agenda in terms of not only addressing the political complexity of the peace process, but also the legal complexity of war-torn societies. ${ }^{8}$ "Much ink has been spilled on the purposes and content of both transitional justice and peacebuilding, and both concepts continue to evolve."

Drawing from the recent international determinations to resolve various crises in Africa, this paper focuses on the increasing interaction between two sides of the same coin of international intervention: TJ and post-conflict peacebuilding as part of the liberal cosmopolitan agenda that has endured since the end of the Cold War. The interaction between these two fields is of crucial concern here, and an examination of how the process of addressing political crisis in Africa is 'becoming' 
increasingly relevant to a debate that is commonly associated with $\mathrm{TJ}$ : how to implement the TJ mechanism through peacebuilding practices. ${ }^{10}$

In this article, the discussion draws from the secondary literature about managing crisis in Africa and the author's recent semi-structure interviews in Kenya, Ethiopia and Sierra Leone as an attempt to critically advance an understanding of how two different fields collude or entwined. The first part begins by revising Richmond's four generations of practices in peacebuilding and its discontents. ${ }^{11} \mathrm{~A}$ particular emphasis will be placed here on the fourth, most contemporary framework for liberal peacebuilding, and the major criticisms that it has received in Africa. Finally, the article acknowledges the sustained criticism of liberal peace in Africa, which is key to understanding the growing relevance of the 'justice versus peace' debate in two specific forms of post-conflict reconstruction experiments in Africa. Firstly, transformation from peacekeeping to peacebuilding, and secondly, a paradigm shift from the normative, liberal peace conviction that justice is a good project, to a legal, consequentialist argument that peace cannot be lastingly sustained without some form of criminal prosecution, resulting the increasing usage of human rights language in peacebuilding. The aim is to highlight the deeper affinity and deficiency that can be viewed as two sides of the same coin in the liberal cosmopolitan approach to post-Cold War International Relations (IR): peacebuilding as a political project concerned with sustainable peace, and TJ as a legal project that concerns itself with evaluating the modes of justice during the transitional phase.

\section{LIBERAL PEACEBUILDING AND ITS CRITICS IN AFRICA}

The end of the Cold War marked an increased focus on intra-state conflicts. As a result, there was an increase in the international determination to resolve these conflicts through peacebuilding missions, rather than by adopting policies that lead to territorial distribution. ${ }^{12}$ The demise of superpower conflicts contributed to a proliferation of international peacebuilding projects. ${ }^{13}$ Although the concept itself was not novel, it received considerable attention from international policymakers and commentators with the 1992 publication of the UN's Agenda for Peace, in which peacebuilding is defined as "action to identify and support structures which will tend to strengthen and solidify peace in order not to relapse into conflict." ${ }^{14}$ The concept was 
later enriched by the 2004 UN Report, which signified its importance in navigating international peace operations in various conflict zones, scattered over four continents. ${ }^{15}$ What is prevalently termed as 'liberal peacebuilding' in Paris' analysis of the features of 'democratization and marketization' that have been evident in peace operations since the 1990 is a call for international society to recognize the 'liberal agenda' in various peace operations including peacekeeping, the rules of law, human rights, humanitarian intervention, immediate election, open market economy, constitutional writing, power sharing and TJ ${ }^{16}$

Yet, as the peace missions became entangled with more complex questions of politics, human rights and security, they came under a sustained barrage of criticism from critical peacebuilding scholarship (CPS) about the heavy involvement of external actors, the recurring cycle of violent conflict and the overreaching goals of peacebuilding missions. ${ }^{17}$ For instance, the recurring cycle of violent conflict in eastern Democratic Republic of Congo (2008) and similar features of protracted conflict in Rwanda (1994) are visible in the recent crisis of Ivory Coast (2011) and South Sudan (2012), since there is continual disagreement as to what types of peacebuilding activities should be prioritized. ${ }^{18}$ Part of the problem lies in the scholarly debate surrounding liberal peacebuilding, in which academics are either for (in the case of those who advocate the problem-solving approach) or against (those who advocate the CPS) the normative foundation of current peacebuilding based on liberal peace theses. ${ }^{19}$

Perhaps the works of Richmond shed some light on the various types of peace that have existed and been connected to the various aforementioned peace operations. ${ }^{20}$ The overlooked analysis of liberal peacebuilding, and the convenient tendency of IR scholarship to analyze state-building and its dependency on violence throughout 'European history', have overshadowed the crucial term of 'peace' itself. ${ }^{21}$ Consequently, according to Richmond, the 'mainstream IR theorists' defined peace as being opposite to war, and focused solely on the state formation's and its institutional arrangements to secure legitimacy, thus discrediting the role of various agents that operated under the radar of the state at the local level. ${ }^{22}$ To Richmond, the understanding of peacebuilding must be distinguished from the predominant understanding of liberal peacebuilding, and institutional approaches that tend to focus on state-building. ${ }^{23}$ Indeed, in his thesis 
on post-conflict peacebuilding in Sierra Leone, Tom confirms that the focus that has been placed on state-building in various peacebuilding projects in Africa since the events of the 11th September of 2001. ${ }^{24}$ This is particularly apparent in countries that are internationally and quantitatively 'ranked' as weak states by the United States, as witnessed in Afghanistan, Iraq and the Horn of Africa. ${ }^{25}$

To propose that it is necessary to distinguish between statebuilding and peacebuilding is not to make the radical proposal that peacebuilding can be developed without a state; rather, it is to highlight that besides the task of rebuilding a state based on a "Western historical model..., realist theoretical approaches (e.g. Morgenthau, Waltz, etc.), to sociology (Weber, Tilly), anthropology (Evans-Pritchard, RadcliffeBrown), history, and economics (Keynes, Marx, Friedman), ${ }^{26}$ there is also an argument to be made that it is dependent on various agencies that appear at the national and sub-national levels, and which are endogenous to the peacebuilding processes itself. This brings us to the Richmond's conceptualization of the four major generations of peacebuilding: the first generation of realists who emerged from predominantly positivist traditions of negative peace, and who believe that conflict is inevitable but manageable; the second generation of scholars of liberal institutionalism in peace and conflict resolution; the third generation of liberal peacebuilding studies conducted from the policymaker's perspective, incorporating the imposition of governance and the top-down approach; finally, there is the generation of critical peacebuilding, with its critics of 'peace-as-governance' and their demands for a broader reconceptualization of peacebuilding as the means by which conflict resolution is transformed into conflict transformation by using the bottom-up approach. ${ }^{27}$ The recent growth in the literature of the fourth generation of CPS opens up further avenues in examining the various activities of peace and justice at the local level. To a certain extent, this recent growth is connected to the critics of the liberal peacebuilding practices applied in an attempt to put an end to the ubiquitous outbreaks of violent conflict in Africa.

Given the call for a further critical review of liberal peacebuilding by CPS, there has been a marked dearth of studies on the impact of such peacebuilding processes in Africa. ${ }^{28}$ However, a growing line of study that criticizes liberal peacebuilding in Africa confirms that the debate on liberal peace has a tendency to tenaciously follow the argument that 
"development is dependent on democracy, and democracy supports peace and stability, further encouraging development." 29 Ironically, what has come to be identified as 'international determinism' since the introduction of the Structural Adjustment Policy (SAP) template (1980) has similarly featured the imposition of procedural democracy or multiparty system of democracy (1990) through aid sanctions, as well as recent TJ experiments in civil wars. ${ }^{30}$ The results of these processes are inimical, but the cost of securing order and security remained high throughout their implementation, and what has been established so far is a 'virtual peace'31 or a 'technocratic peace'32. This type of peace seemingly functions at the surface level of the post-colonial state and is manifested by the ruling elite's rhetorical commitment to peace, which does not actually benefit those who were subjected to violence. ${ }^{33}$

Liberal peacebuilding missions have continually failed to transform the neo-patrimonial logic of the state in the post-conflict environments of Angola, Liberia, Mozambique, Rwanda and South Sudan, and have inevitably produced unintended consequences of renewed violence, unequal access to economic resources, illiberal power alternation and flawed elections. ${ }^{34}$ Liberal peace have not only failed to reform the neo-patrimonial system that caused the crisis, have continually relied on the existence of such a system (because of the lack of internal hegemony) in securing immediate peace and compromising with peace spoilers. ${ }^{35}$

Consequently, the contextualization of peacebuilding in a neoliberal sense "is conventionally understood as principally a product of force, patronage, and power, including external power (as in post-colonial Africa), rather than recognition or to achieve a range of core functions. ${ }^{" 36}$ As a result, the study of rebuilding a state in Paul Collier's quixotic terming of 'dangerous places like Africa' ${ }^{37}$ has not only ignored what Curtis and Dzinesa ${ }^{38}$ identify as 'power relations' and 'local ownership', but also resembles the déjà vu evidence that the "[p]ost-colonial processes of state formation are, in particular, assumed to imply an illiberal social contract where state resources are used in various ways to support elites and to buy off citizens, preserving local patterns of power responsible...." ${ }^{39}$ In this case, the "patterns of power' are responsible for the repressive state that had existed before the eruption of the crisis. 
Owing to such deficiencies of liberal peace in Africa, I argue that the above mentioned key debates surrounding liberal peacebuilding and its critics in Africa are indicative of the growing trend where recent post-conflict peacebuilding intervention 'becoming' as parts of the TJ efforts. This gives an indication of why there is a widespread concern that the international attempts to secure peace and democracy may plausibly intersected with efforts to address criminal accountability and mass atrocity in Zimbabwe ${ }^{40}$, Nigeria ${ }^{41}$, the Ivory Coast ${ }^{42}$, Mali $^{43}$ and Libya ${ }^{44}$ in their attempts to deal with their crises. Due to an increasing emphasis on the rule of law and peacebuilding practices, liberal peace model of conflict resolutions have come to be associated with a vague demand for criminal accountability at the expense of TJ mechanisms. ${ }^{45}$ One of the oddities of this post-conflict reconstruction model is the multiple, hybrid mechanisms of TJ; and the intersection of its mechanism with an international peacebuilding agenda. ${ }^{46}$ This has expanded the general understanding of justice, which now seems ideal in theory but elusive in practice. This trend should not be neglected, and the increasing nexus and nemesis between 'justice and peace' is discussed next.

\section{FROM PEACEMAKING TO PEACEBUILDING}

In relation to the above discussion of the recent developments in the field of peacebuilding, it is important to remember that, since the 1990s, it has had an increasingly profound effect on the development of TJ. One instance in which it has exerted its influence on the latter can be seen in Galtung's research on 'negative peace'. ${ }^{47}$ Negative peace is a condition that is achieved in the absence of war or direct violence, while positive peace refers to the absence of structural conditions that may produce a protracted conflict. Indeed, Galtung's extended definition of violence and conflict leads to an extended definition of peacebuilding and $\mathrm{TJ} .{ }^{48}$ By connecting violence to the structure of society, peacebuilding is understood to constitute a wide range of activities, including a focus on justice. "Peacebuilding tools such as judicial liberal reform, reform of the security forces and the inclusion of former rebels and vetted former members of security forces are also often explicitly tied to processes of transitional justice." 49 For instance, the UN's peacemaking missions in Rwanda have seen an increased application of international law in responding to the longterm objectives of peacebuilding vis-à-vis TJ mechanisms. ${ }^{50}$ However, 
the expansion of peacebuilding to include $\mathrm{TJ}$ creates a further difficulty in evaluating its success.

In assessing the ineffectiveness of peacebuilding missions in Rwanda, Zartman have observed that the chief problem lies in the way that peacebuilding has been promoted.$^{51}$ These peacebuilding missions were made more complicated by the inclusion of TJ in their objectives. The missions in Rwanda were complicated by the implementation of the International Criminal Tribunal for Rwanda (ICTR) and the Gacaca courts. Initially, the United Nations Assistance Mission for Rwanda (UNAMIR) was enforced in order to facilitate the Arusha agreements. However, through UN resolutions 1995, UNAMIR's objectives were broadened to include assisting the Rwandan government with justice and reconciliation. ${ }^{52}$ The integration of the ICTR into the peacebuilding missions has been criticized for getting the rhetoric right, but the strategy wrong. Since its inception, the ICTR has cost nearly one billion pounds, but has only succeeded in putting forty-three people behind bars. There have been twelve others indicted, but the court subsequently freed the after the judges dismissed their cases on the basis of legal technicality errors. ${ }^{53}$

In short, there has been continued criticism of not only the increased expenditure of the court, but also of the slow implementation of justice measures for establishing peace and enabling reconciliation. ${ }^{54}$ Although immediate peace has been restored since then, the difficulty of achieving retributive justice in Rwanda strengthens the perception that peacebuilding is highly unlikely to restore peace in the long-term. ${ }^{55}$ This galvanizes the issues of the existing debate between peace and justice in the post-conflict reconstruction agenda.

\section{FROM LIBERAL COSMOPOLITAN TO LEGAL CONSEQUENTIALIST: IMPLEMENTING HUMAN RIGHTS IN PEACEBUILDING MISSIONS}

In framing the relationship between peacebuilding and TJ, arguably, both share a liberal cosmopolitan vision of IR. ${ }^{56}$ Being a product of the Western Enlightenment, the liberal institutionalist project of the 20th century prioritizes "political freedom, democracy and constitutionally guaranteed rights, and [advocates] the liberty of the individual and equality before the law, ${ }^{\prime 57}$ whereas cosmopolitanism can be understood 
as being an ideology based on a "consciousness of being a citizen of the world." It is a projection of a "worldwide community of human beings," which "seeks to reframe human activity and entrench it in law, rights, and responsibilities," therefore upholding the "irreducible moral status of each and every person." ${ }^{58}$ As a result, a combination of liberal cosmopolitanism's emphasis upon individual human beings, seeks to challenge the state's exclusive position as the primary moral actor in IR. ${ }^{59}$

By the end of the Cold War, the transition from state security to human security has provided international space for the liberal cosmopolitan conviction of the necessity of bringing the law in peacebuilding, humanitarian crisis management and TJ. This ideology has inspired international attempts to pursue justice through peacebuilding; the general view is now that the quest for justice is part of the original vision of peacebuilding. Indeed, the UN strongly emphasizes that there is no peace without criminal prosecution. The transition from the process of securing peace agreement to that of establishing a long-term peacebuilding project necessitates the administering of some forms of justice. ${ }^{60}$

Most important among these is criminal prosecution, since the causes of violence are often related to impunity. Impunity is inherent in the renewed cycle of violence, and addressing impunity with certain judicial measures is a precondition to deterring future conflict. ${ }^{61}$ In sentencing Charles Taylor, the Special Court for Sierra Leone (SCSL) acknowledged that the primary objectives of justice were retribution and deterrence. Obviously, retribution was emphasized by the SCSL in order to acknowledge international concerns about the serious violations of human rights. ${ }^{62}$ The consequence of the verdicts also indicates that the retributive energies of the SCSL need to be tempered by the restorative aims of the Sierra Leone's Truth and Reconciliation Commission (TRC). ${ }^{63}$ This is so that any future violations can be deterred with the help of both the restorative and retributive elements of TJ mechanisms. These goals are in line with those of international agents, who side with liberal cosmopolitanism in their conviction that justice and peace must be pursued simultaneously. The pursuit of justice in the signing of the recent peace agreement in Zimbabwe and Kenya demonstrates the above argument. ${ }^{64}$ 
While the traditional positions of TJ practitioners have always maintained the importance of the impartiality of justice in peacebuilding, the ICC's prosecutor, Bensouda, goes on to claim that "[p]eace and justice are two sides of the same coin." ${ }^{55}$ In line with Bensouda's claim, Kenyan human rights activists argue that justice could be a means of preventing future election violence. ${ }^{66}$ However, the increasing appearance of ICC officers in nearly every crisis in Africa has marked a normative shift from the simple moral advocacy of justice towards a legal consequentialist approach. To a certain extent, this challenges the existential functionality or legitimacy of the ICC. ${ }^{67}$

Pursuing justice in the midst of conflict is usually a matter of political compromise, as almost every agent has a different conception of what constitutes a just society. The aims of recent Kenyan diplomatic missions to the UN Security Council (UNSC) may seem contradictory to the argument presented by Bensouda and the Kenyan human rights activist. ${ }^{68}$ The mission requests the UNSC to terminate the ICC's intervention on the basis that the pursuit of justice is destabilizing the security of the country. While the UNSC may dismiss Kenya's request as being more about shielding impunity than maintaining security (since the ICC's chief suspect is currently sitting as Kenya's head of the state), the request obviously espouses the view that the pursuit of justice is incompatible with establishing peace. ${ }^{69}$

Nevertheless, the debate about the relationship between peace and justice constitutes a paradigm shift in justifying the reasons for the international policymaker to promote TJ through peacebuilding. The moral, liberal cosmopolitan argument that justice is simply a 'good project' has developed into a legal consequentialist argument, which asserts that the pursuit of justice is a 'requirement for establishing peace'.$^{70}$ Consequentialist arguments have therefore contributed to a broader understanding of TJ, in which the pursuit of justice (through the ICC) is not only about dealing with past atrocities, but is also a kind of 'bargaining chip' that shapes the formulation of the power-sharing deal in Kenya and humanitarian intervention in Libya. ${ }^{71}$

Meanwhile, the increase in the ratifications of international human rights documents has helped to facilitate the co-existence of human rights and humanitarian laws in peacebuilding missions. In particular, this has been achieved through the integration of various 
international human rights documents with the enforcement of the Rome Statute of the International Criminal Court (ICC) ${ }^{72}$ As a result, this has produced an increased focus on the language of human rights in peacebuilding missions across the globe. Human rights provide a type of language with which a post-conflict reconstruction agenda can contextualize TJ, violation and crimes against humanity. ${ }^{73}$

By the 1990s, only a few of the peacebuilding missions that ended civil war had included amnesty bargains, such as the peace processes in Liberia (1993) and Sierra Leone (1999). Unfortunately, the particular amnesty bargains within these peace processes were not recognized by international human rights and criminal law, and could not be isolated from the globalizing norms of crimes against humanity. As a result, the SCSL did not recognize the amnesty bargain that was produced by the Lome Peace Accord. ${ }^{74}$ Learning from the pitfalls of the Sierra Leone peace process, all subsequent mediations of peace processes and power-sharing arrangements in Sudan, Uganda, Burundi, Zimbabwe, Ivory Coast and Kenya have prescribed a notably limited amnesty (in some cases abandoned afterwards), calling for more criminal indictments, trials, institutional reforms and reconciliations on a national level.

By 2000, most peacebuilding missions under the banner of the $\mathrm{UN}$ and the AU had begun to integrate various TJ measures as part of effecting the transition to peace. For example, around the time of Kenya's attempt to deal with postelection violence, TJ appeared to be a predominant theme of peacebuilding. Particularly, South Africa's TRC and the ICC's 18 cases mostly reinforced the UN, the African Union and Kenyan civil society's perceptions that a viable solution to post-election violence could only be found in the integration of TJ as part of the power sharing deal. ${ }^{75}$

Hence, the interaction between $\mathrm{TJ}$ and liberal peacebuilding exhibits a precarious condition for navigating law and politics in post-conflict reconstruction studies. However, I also suggests that the success of this interaction depends on the ability of the international society to understand that a liberal cosmopolitan conviction of justice, peace, reconciliation, accountability and mitigating impunity via TJ mechanisms-the ICC and the TRC-has not addressed the needs of the victims or succeeded in combating the infamous legacy of impunity in 
African Politics. The utilitarian approach to understanding retributive and restorative theories of $\mathrm{TJ}$ is inimical and univariate, and excludes the local political contingency of African history. Consequently, it fails to provide a sound understanding of the power relations and local ownership of the ICC and TRC in the neo-patrimonial logic of African politics.

When implemented in liberal peacebuilding paradigms, advocates of TJ argue that its mechanism facilitates a wider access to justice and promotes greater democratization. Yet there is a need of future research to illuminate how TJ becomes part of the existing attempts to implement democratization, rather than signifying democratic transition in Africa. There is an overwhelming tendency in the literature of TJ to treat TJ experiments in post-authorities environment in Latin America and Eastern European countries as similar to the current situation concerning the consolidation of democracy and post-conflict peacebuilding in African countries. While integrating TJ with broader liberal peacebuilding concerns leads to broader institutional reforms projects, as are currently being witnessed in Kenya, Sierra Leone, Ivory Coast and Libya, evidence to this date suggested that neither the ICC nor the TRC proceedings are directly connected to the victims' ordinary or everyday understanding of justice and reconciliation. ${ }^{76}$

\section{CONCLUSION}

In terms of theory and practice, both peacebuilding and TJ have been isolated from each other in the past but now share certain common assumptions about rescuing victims or members of the population who live in the conflict zone. Therefore, it can be argued that TJ and liberal peacebuilding have become entangled, and share a deeper affinity with the liberal cosmopolitan ideas of post-Cold War IR. The peacebuilding objectives of addressing impunity, strengthening the rule of law and drafting constitutions provides a plausible explanation of the present and future direction of researching TJ through peacebuilding practices. It can be concluded that, while the interaction between $\mathrm{TJ}$ and peacebuilding is provided with a nexus by epistemological assumptions about victimhood, TJ and peacebuilding can also become nemeses when their hybrid practices are not connected to the victim actual needs and concerns. 
The debate about the most suitable mechanism with which to deal with the past atrocity as part of the liberal peacebuilding agenda has ventured into dangerous terrain, in which TJ is recognized as a permissible form of justice despite being indeterminate in forming a realistic strategy for post-conflict reconstruction. The adoption of $\mathrm{TJ}$ through peacebuilding practices provides a unique view of justice during the transitional period as an exceptional instance of law in post-conflict societies. However, the danger of viewing TJ in this way lies in the agents' tendency to manipulate human rights. Once it has been deemed to be 'transitional', TJ can be characterized as being beyond the straightforward understanding of justice. The deep, normative commitment to human rights language reduces $\mathrm{TJ}$ to a strategic toolkit, or a mechanism that is up for grabs for any powerful actor or peace-spoiler that wishes to wage war, prosecute enemies, or manipulate victims.

The consequence for Africa is very obvious here: the complex task of resolving the political crisis confirms the increasing necessity of an interesting interaction between TJ and liberal peacebuilding. Yet the interaction between both fields has generated more of an international engagement with Africa's heterogeneous societies in the long-term, but in the short-term it has duplicated the existing deficiencies of the technocratic and institutional focus on good governance, the SAPs' templates, democratic reforms and human rights struggles. The pursuit of TJ through liberal peacebuilding practices reveals the complexity of restoring order, and that the rule of law is heavily conditioned by politics. For instance, navigating law and politics in both TJ and peacebuilding confirms Cameron's identification of the 'fascinating intricacy' of the interaction between institutions of international law and international politics in post-genocide environment of Rwanda. ${ }^{77}$ Cameron concludes that an understandings of politics as the act of manipulation by the international elite is not immediately obvious to the casual observer. Such a tacit understanding of power and politics results in the creation of circumstances in which the western countries' ability to perform the immediate tasks of upholding human rights and preventing genocide is highly influenced by their geostrategic and economic interests in Africa.

In current ICC's situation in Kenya, the moribund state of the ICC's judicial administration, and the inconsistent stances of the 
western partners in relation to its proceedings, reveal the 'fascinating intricacy' between law and politics. ${ }^{78}$ Evidence from the TJ experiments in Rwanda, Sierra Leone, Libya and Kenya has confirmed that while the 'increased judicialization' of the liberal peace means of dealing with mass atrocities has marked the imperative locations of global constitutional order as imposed by international policymakers, the corrective approach to the flaws of one-size-for-all solutions has not only repeatedly failed to recognize the problem to maintaining peace by using a top-down approach, but that these flaws are also apparent in the form of legal pluralism. ${ }^{79}$ 'Pluralism' is used here in the sense that various TJ mechanisms "represent a diversification and localization that moves away from international centralized modes of justice," and that what is comprehended as rooted from Africa "operates alongside formal institutions, whether national or international." 80 In such instances, legal pluralist approached to liberal peace and TJ resembles the dual practices of law and political order during the colonial time. This renewed the post-colonial sentiments and hostile receptions of the ICC among the AU leaders.

Equally important is the fact that, while the ICC's quest to deliver justice is largely conditioned by external politics, the African ruling class played a significant role in obstructing the justice cascade. ${ }^{81}$ The debate surrounding TJ and liberal peace in Africa challenges the tacit assumption that the agent (the African leader) is a passive bystander, and is systematically victimized by the preordained structure of the post-colonial state system and the imposition of international order upon African society. Indeed, since the period of independence, the nature of the states has evolved. Their leaders are now capable of making strategic calculations; of exploiting certain liberal cosmopolitan agendas in foreign policy (such as those of the ICC and TJRC); of hiding under the peculiar cloak of post-colonialism by romanticizing the uniqueness of African societies, and of rejecting a wider call for reforms and denying the victim's rights. ${ }^{82}$

The current ICC's hostile receptions among the African leaders have reinvigorated an all-too-familiar debate about the misleading trade-off between accountability and impunity, or between justice and peace. Such misleading trade-off exhibited in Vinjamuri's criticism of the proponents of the 'justice cascade' in international politics. ${ }^{83} \mathrm{In}$ her critical reflection on Sikkink's famous thesis concerning justice 
cascade,${ }^{84}$ she describe the moribund nature of ICC's proceedings in Kenya and Libya, suggesting them as a 'justice casket' rather than a justice cascade. This illustrates a clear indication of the dilemma of striking a balance between moral utopia and realpolitik in human rights agenda.

\section{NOTES}

1 This article would not have been possible without the help of many advocates for democracy and human rights in Kenya, Ethiopia and Sierra Leone, who generously granted interviews, which were often lengthy. I am also indebted to Nic Cheesman (Oxford) and Gabrielle Lynch (Warwick) for sharing their insights on Transitional Justice in Africa, and to Pete Breat (SOAS), Jane Smith (Stanford), and Michelle Hans (Science Po, Paris) for their comments on portions of earlier versions.

2 Sultan Barakat and Thomas Waldman, "Conflict Analysis for the TwentyFirst Century," Conflict, Security \& Development, Vol. 13, No. 3, 2013, p. 275.

3 Jemima Garcia-Godos and Chandra Lekha Sriram, "Introduction," in Chandra Lekha Sriram, et al. (eds.), Transitional Justice and Peacebuilding on the Ground: Victims and Ex-Combatants, London: Routledge, 2013, p. 1.

4 Alexander Boraine, "Transitional Justice: A Holistic Interpretation," Journal of International Affairs, Vol. 60, No. 1, 2006, p. 18.

5 Ruti Teitel, Transitional Justice, Oxford: Oxford University Press, 2000, p. 25.

6 For a useful discussion on the historical development of TJ, see Neil Kritz, Transitional Justice: How Emerging Democracies Reckon with Former Regimes, Washington, DC: US Institute of Peace (USIP), 1995.

7 See Luc Huyse and Mark Salter (eds.), Traditional Justice and Reconciliation after Violence Conflict: Learning from African Experiences, Stockholm: International Institute for Democracy and Electoral Assistance (International IDEA), 2008.

8 United Nations, "Report of the Secretary-General: The Rule of Law and Transitional Justice in Conflict and Post-Conflict Societies," <http:// daccess-dds-ny.un.org/doc/UNDOC/GEN/N04/395/29/PDF/N0439529. pdf?OpenElement>

9 Garcia-Godos and Sriram, "Introduction," p. 12.

10 Lydiah Bosire, Overpromised, Undelivered: Transitional Justice in SubSaharan Africa, New York: International Centre for Transitional Justice, 2006. 
11 See Oliver P. Richmond, The Transformation of Peace, London: Palgrave, 2005.

12 Roland Paris, At War's End: Building Peace after Civil War, Cambridge: Cambridge University Press, 2004, p. 24.

13 Vivienne Jabri, "Peacebuilding, the Local and the International: A Colonial or a Postcolonial Rationality?," Peacebuilding, Vol. 1, No. 1, 2013, p.7.

14 Boutros Boutros-Ghali, "An Agenda for Peace," <http://www.undocuments.net/a47-277.htm>

15 See United Nations, "Report of the Secretary-General."

16 Paris, At War's End, p. 27.

17 For a useful discussion on CPS, see Oliver P. Richmond (ed.), Palgrave Advances in Peacebuilding: Critical Developments and Approaches, New York: Palgrave, 2010.

18 Devon Curtis, "The Limits to Statebuilding for Peace in Africa," South African Journal of International Affairs, Vol. 20, No. 1, 2013, p. 81.

19 Oliver P. Richmond, Peace in International Relations, New York: Routledge, 2008, p. 7.

20 See Richmond, The Transformation of Peace.

21 Ibid., p. 204

22 Oliver P. Richmond, "Critical Research Agendas for Peace: The Missing Link in the Study of International Relations," Alternatives, Vol. 32, No. 2, 2007, p. 248.

23 Oliver P. Richmond, A Post-Liberal Peace, London: Routledge, 2011, p. 11.

24 Patrick Tom, "The Liberal Peace and Post-Conflict Peacebuilding in Africa: Sierra Leone," Ph.D. Thesis, St Andrews, Scotland: University of St Andrews, 2011, p. 87.

25 Ibid., p. 88.

26 Ibid., p. 300.

27 Richmond, The Transformation of Peace.

28 Tom, "The Liberal Peace and Post-Conflict Peacebuilding in Africa," p. 111.

29 Rita Abrahamsen, "Development Policy and the Democratic Peace in Sub-Saharan Africa," Conflict, Security \& Development, Vol. 1, No. 3, 2001, p. 80 .

30 Susan Willett, "New Barbarians at the Gate: Losing the Liberal Peace in Africa," Review of African Political Economy, Vol. 32, No. 106, 2005, p. 587. 
31 Ian Taylor, "What Fit for the Liberal Peace in Africa?," Global Society, Vol. 21, No. 4, 2007, p. 558.

32 Roger MacGinty, International Peacebuilding and Local Resistance, New York: Palgrave Macmillan, 2011, p. 495.

33 Taylor, "What Fit for the Liberal Peace in Africa?," p. 559.

34 Devon Curtis and Gwinyayi Albert Dzinesa, Peacebuilding, Power and Politics in Africa, Athens, OH: Ohio University Press, 2012, p. 17.

35 Taylor, "What Fit for the Liberal Peace in Africa?," p. 566.

36 Oliver P. Richmond, "The Legacy of State Formation Theory for Peacebuilding and Statebuilding," International Peacekeeping, Vol. 20, Iss. 3, 2013, p. 302.

37 See Paul Collier, Wars, Guns and Votes: Democracy in Dangerous Places, London: Vintage, 2010.

38 Curtis and Dzinesa, Peacebuilding, Power and Politics in Africa, p. 25.

39 Richmond, "The Legacy of State Formation Theory for Peacebuilding and Statebuilding," p. 302.

40 Conrad Nyamutata, "Electoral Conflict and Justice: The Case of Zimbabwe," African Journal of Legal Studies, Vol. 5, No. 1, 2012, p. 85.

${ }^{41}$ Vanessa Ushie, "Nigeria's Amnesty Programme as a Peacebuilding Infrastructure: A Silver Bullet?," Journal of Peacebuilding \& Development, Vol. 8, No. 1, 2013, p. 35.

42 Giulia Piccolino, "Ultranationalism, Democracy and the Law: Insights from Cote Divoire," The Journal of Modern African Studies, Vol. 52, No. 1, 2014, p. 426.

43 Djallil Lounnas, "The Regional Fallouts of the French Intervention in Mali," Mediterranean Politics, Vol. 18, No. 2, 2013, p. 327.

44 Phillip Apuuli Kasaija, "The African Union (A.U.), the Libya Crisis and the Notion of 'African Solutions to African Problems'," Journal of Contemporary African Studies, Vol. 31, No. 1, 2013, p. 118.

45 Mireilla Affa'a Mindzie, "Transitional Justice, Democratisation and the Rule of the Law," in Chandra Lekha Sriram and Suren Pillay (eds.), Peace Versus Justice: The Dilemma of Transitional Justice in Africa, Cape Town: University of Kwazulu-Natal Press, 2010, p. 114.

46 See Chandra Lekha Sriram, "Justice as Peace? Liberal Peacebuilding and Strategies of Transitional Justice," Global Society, Vol. 21, No. 4, 2007, pp. 579-591.

47 See Johan Galtung, Peace, War and Defence: Essays in Peace Research, Copenhagen: Christian Ejlers, 1975.

48 Oliver Ramsbotham, Tom Woodhouse and Hugh Miall, Contemporary Conflict Resolution, Cambridge: Polity Press, 2007, p. 208. 
49 Sriram, “Justice as Peace?," p. 285.

50 See Bert Ingelaere, "Living the Transition: Inside Rwanda's Conflict Cycle at the Grassroots," Journal of Eastern African Studies, Vol. 3, No. 3 , 2009, pp .438-463.

51 I. William Zartman, "The Timing of Peace Initiatives: Hurting Stalemates and Ripe Moments," Global Review of Ethnopolitics, Vol. 1, No. 1, 2001, p. 15.

52 United Nations, "Security Council Resolution 995 - Establishing the Criminal Tribunal for Rwanda," <http://www.un.org/en/peacekeeping/ missions/past/unamirM.htm>

53 Mike Pflanz, "UN's Special Genocide Tribunal for Rwanda a Waste of Time," The Telegraph, 4 February 2013, <http://www.telegraph.co.uk/news/ worldnews/africanandindianocean/rwanda/9848588/UNs-special-genocidetribunal-for-Rwanda-a-waste-of-time.html>

54 Interview with an African Union officer \#1, Addis Ababa, 14 April 2012. 55 Interview with ICTR Prosecutorial Office, officer \#1, Kigali, 18 June 2012.

56 Lisa J. Laplante, "Transitional Justice and Peace Building: Diagnosing and Addressing the Socioeconomic Roots of Violence through a Human Rights Framework," International Journal of Transitional Justice, Vol. 2, No. 3, 2008, p. 332.

57 Scott Burchill, "Liberalism," in Scott Burchill, et al. (eds.), Theories of International Relations, New York: Palgrave Macmillan, 2005, p. 55.

58 Robert Fine, "Cosmopolitanism: A Social Science Research Agenda," in Gerard Delanty (ed.), Handbook of Contemporary European Social Theory, London: Routledge, 2006, pp. 242-243.

59 Steven C. Roach, "Value Pluralism, Liberalism, and the Cosmopolitan Intent of the International Criminal Court," Journal of Human Rights, Vol. 4, No. 4, 2005, p. 482.

60 See Sriram and Pillay (eds.), Peace Versus Justice.

${ }^{61}$ Charles Manga Fombad and Enyinna Nwauche, "Africa's Imperial Presidents: Immunity, Impunity and Accountability," African Journal of Legal Studies, Vol. 5, No. 2, 2012, p. 97.

62 Special Court for Sierra Leone, Sentencing Judgment (Prosecutor vs. Charley Gankay Taylor), Freetown (SL): The Special Court for Sierra Leone, 2012, p. 1285.

${ }^{63}$ Priscilla B. Hayner, "The International Role in Justice and Peacemaking in Sierra Leone," International Justice and the Prevention of Atrocities, Berlin: European Council on Foreign Relations (ECFR), 2013. 
${ }^{64}$ See Nic Cheeseman and Blessing-Miles Tendi, "Power-Sharing in Comparative Perspective: The Dynamics of 'Unity Government' in Kenya and Zimbabwe," The Journal of Modern African Studies, Vol. 48, No. 2, 2010, pp. 203-299.

65 Fatou Bensouda, "International Justice and Diplomacy," The New York Times, 20 March 2013, <http://www.nytimes.com/2013/03/20/ opinion/global/the-role-of-the-icc-in-international-justice-and-diplomacy. $\mathrm{html}$ ?smid $=$ tw-share\& $\mathrm{r}=5 \&>$

66 Interview with Kenyan National Human Rights Commission officer \#2, Nairobi, 2 March 2012.

67 Giulia Piccolino and John Karlsrud, "Withering Consent, but Mutual Dependency: UN Peace Operations and African Assertiveness," Conflict, Security \& Development, Vol. 11, No. 4, 2011, p. 467.

68 "Kenya Asks UN to Halt ICC Charges against Kenyatta," BBC News, 9 May 2013, <http://www.bbc.co.uk/news/world-africa-22472242>

69 Interview with the ICC officer, The Hague, 12 February 2013.

70 Kieran McEvoy, "Letting Go of Legalism: Developing a Thicker Version of Transitional Justice," in Kieran McEvoy and Lorna McGregor (eds.), Transitional Justice from Below, London: Hart Publisher, 2008, p. 16.

71 Jack Snyder and Leslie Vinjamuri, "Principled Pragmatism and the Logic of Consequences," International Theory, Vol. 4, No. 3, 2012, p. 472.

72 Christine Bell, On the Law of Peace: Peace Agreement and the Lex Pacificatoria, Oxford: Oxford University Press, 2008, p .78.

73 Owen Fiss, "Within Reach of the State: Prosecuting Atrocities in Africa," Human Rights Quarterly, Vol. 31, No. 2009, p. 60.

74 Tim Kelsall, Culture under Cross-Examination: International Justice and the Special Court for Sierra Leone, Cambridge: Cambridge University Press, 2009, p. 229.

75 Interview with Kenyan Government Official, Nairobi, 17 March 2012.

76 Ifeonu Eberechi, "Armed Conflicts in Africa and Western Complicity: A Disincentive for African Union's Cooperation with the ICC," African Journal of Legal Studies, Vol. 3, No. 2009, p. 74.

77 Hazel Cameron, "British Complicity in Genocide Rwanda 1994," State Crime, Vol. 1, No. 1, 2012, p. 71.

78 See Stephen Brown and Rosalind Raddatz, "Dire Consequence or Empty Threats? Western Pressure for Peace, Justice and Democracy in Kenya," Journal of Eastern African Studies, 2014, pp. 1-22.

79 See Phil Clark, Debating International Justice in Africa : Collected Essays, 2008-2010, Oxford: University of Oxford Centre for Socio-Legal Studies, 2010. 
80 Rosemary Nagy, "Centralizing Legal Pluralism? Transitional Justice in Transitional Context," in Chandra Lekha Sriram, et al. (eds.), Transitional Justice and Peacebuilding on the Ground: Victims and Ex-Combatants, London: Routledge, 2013, p. 81.

81 Stephen Brown and Chandra Lekha Sriram, "The Big Fish Won't Fry Themselves: Criminal Accountability for Post-Election Violence in Kenya," African Affairs, Vol. 111, No. 443, 2012, p. 257.

${ }^{82}$ Ian Taylor, "Blind Spots in Analyzing Africa's Place in World Politics," Global Governance, Vol. 10, No. 4, 2004; Crawford Young, "The End of the Post-Colonial State in Africa? Reflections on Changing African Political Dynamic," African Affairs, Vol. 103, No. 410, 2004; and William Brown and Sophie Harman, "Introduction: African Agency in International Politics," in William Brown and Sophie Harman (eds.), African Agency in International Politics, London: Routledge, 2013.

${ }^{83}$ Leslie Vinjamuri, "Review of Kathryn Sikkink's the Justice Cascade: How Human Rights Prosecutions Are Changing World Politics," Journal of Human Rights, Vol. 11, No. 2, 2012, p. 286.

84 See Ellen Lutz and Kathryn Sikkink, "The Justice Cascade: The Evolution and Impact of Foreign Human Rights Trials in Latin America," Chicago Journal of International Law, Vol. 2, No. 1, 2001, pp. 1-33. 